\title{
Dissolution test of various low-dose acetylsalicylic acid preparations marketed in Indonesia
}

\author{
Yeyet C. Sumirtapura, ${ }^{1}$ Arini Setiawati, ${ }^{2}$ Jessie S. Pamudji, ${ }^{1}$ Heni Rachmawati. ${ }^{1}$ \\ ${ }^{1}$ School of Pharmacy, Bandung Institute of Technology, Bandung, Indonesia. \\ ${ }^{2}$ Department of Pharmacology \& Therapeutics, Faculty of Medicine, University of Indonesia, Jakarta, Indonesia.
}

\begin{abstract}
Abstrak
Tujuan Membandingkan profil disolusi berbagai tablet asam asetilsalisilat dosis rendah salut enterik yang dipasarkan di Indonesia.

Metode Studi disolusi dilakukan mengikuti Farmakope Amerika (USP)/Eropa, metode A, menggunakan alat 1 USP (keranjang) $100 \mathrm{rpm}$, dengan 2 media: 0,1 N HCl, 120 menit untuk stadium asam, dan buffer fosfat pH 6,8, 90 menit untuk stadium dapar. Sampel diambil pada 120 menit untuk stadium asam, dan setiap 10 menit sampai dengan 90 menit untuk stadium dapar. Asam asetilsalisilat diukur kadarnya dengan spektrofotometer pada $280 \mathrm{~nm}$ untuk stadium asam, dan pada $265 \mathrm{~nm}$ untuk stadium dapar. Asam salisilat bebas diukur kadarnya hanya pada akhir stadium dapar dengan metode HPLC. Ada 6 produk uji (Cardio Aspirin ${ }^{\circledR} 100$ mg, Aptor ${ }^{\mathbb{B}} 100$ mg, Ascardia ${ }^{\circledR} 80$ mg, Thrombo Aspilet ${ }^{\mathbb{B}} 80$ mg, Astika ${ }^{\circledR} 100$ mg dan Farmasal ${ }^{\circledR} 100 \mathrm{mg}$ ), 3 batch untuk setiap produk, dan 6 unit untuk setiap batch.
\end{abstract}

Hasil Jumlah asam asetilsalisilat yang dilepaskan dari setiap produk asam asetilsalisilat yang diuji pada akhir stadium asam (120 menit) berkisar dari 1,79\% untuk Cardio Aspirin ${ }^{\circledR}$ sampai 6,92\% untuk Thrombo Aspilet ${ }^{\circledR}$, semua produk memenuhi persyaratan farmakope sebagai produk salut enterik $(<10 \%)$. Jumlah asam salisilat yang diamati pada akhir uji disolusi berkisar dari 3,47\% untuk Cardio Aspirin ${ }^{\circledR}$ sampai 10,90\% untuk Astika ${ }^{\circledR}$ dan 11,90\% untuk Thrombo Aspilet $^{\mathbb{R}}$. Thrombo Aspilet ${ }^{\mathbb{B}}$ menunjukkan sifat lepas lambat, yang menyebabkan variabilitas yang sedemikian tinggi dalam melepaskan asam asetilsalisilat, sehingga salah satu dari 3 batch yang diuji tidak memenuhi persyaratan kompendial yaitu lebih dari 75\% (pelepasan hanya 55,11\%). Variabilitas yang tinggi dalam melepaskan asam asetilsalisilat antar batch juga ditemukan pada Farmasal ${ }^{\mathbb{B}}$ pada 10, 20, dan 30 menit dalam medium dapar. Dosis efektif asam asetilsalisilat terendah sebagai obat antiplatelet untuk penggunaan jangka panjang adalah $75 \mathrm{mg}$ asam asetilsalisilat sebagai tablet biasa, yang ekivalen dengan $100 \mathrm{mg}$ asam asetilsalisilat sebagai tablet salut enterik.

Kesimpulan Semua sediaan asam asetilsalisilat dosis rendah yang dipasarkan di Indonesia, merupakan produk salut enterik, sedangkan Thrombo Aspilet ${ }^{\mathbb{B}}$ selain salut enterik juga merupakan produk lepas lambat. Cardio Aspirin ${ }^{\circledR}$, diikuti Aptor $^{\circledR}$, mempunyai dosis yang tepat untuk sediaan dosis rendah salut enterik (100 mg), konsisten dalam melepaskan asam asetilsalisilat antar batch, dan paling stabil terhadap deasetilasi (inaktivasi antiplatelet). (Med J Indones 2009; 18: 161-6).

\begin{abstract}
Abstrak
Aim To compare the dissolution profiles of various enteric-coated low-dose acetylsalicylic acid (ASA) tablets marketed in Indonesia.

Methods The dissolution study was carried out according to US Pharmacocopoeiae (USP) /European Pharmacopoeiae, method A, using USP apparatus 1 (basket) $100 \mathrm{rpm}$, with 2 media: $0.1 \mathrm{~N} \mathrm{HCl}, 120$ minutes for acid stage, and phosphate buffer $\mathrm{pH}$ 6.8, 90 minutes for buffer stage. The sampling points were 120 minutes for the acid stage, and every 10 minutes until 90 minutes for the buffer stage. The acetylsalicylic acid was assayed using spectrophotometry at $280 \mathrm{~nm}$ for the acid stage, and at $265 \mathrm{~nm}$ for the buffer stage. The free salicylic acid was determined only at the end of the buffer stage with HPLC method. There were 6 test products (Cardio Aspirin ${ }^{\circledR} 100 \mathrm{mg}$, Aptor $^{\circledR} 100 \mathrm{mg}$, Ascardia ${ }^{\circledR} 80 \mathrm{mg}$, Thrombo Aspilet ${ }^{\mathbb{B}} 80 \mathrm{mg}$, Astika $^{\circledR} 100 \mathrm{mg}$ and Farmasal $\left.{ }^{\circledR} 100 \mathrm{mg}\right), 3$ batches for each product, and 6 units for each batch

Results The amount of ASA released from each ASA product tested at the end of acid stage (120 minutes) ranged from $1.79 \%$ for Cardio Aspirin ${ }^{\circledR}$ to $6.92 \%$ for Thrombo Aspilet ${ }^{\circledR}$, all conformed to the compendial requirement for enteric-coated product $(<10 \%)$. The amount of salicylic acid observed at the end of the dissolution test ranged from $3.47 \%$ for Cardio Aspirin $^{\circledR}$ to $10.90 \%$ for Astika ${ }^{\circledR}$ and $11.90 \%$ for Thrombo Aspilet ${ }^{\circledR}$. Thrombo Aspilet ${ }^{\circledR}$ showed sustained-release properties, causing high variability in ASA release, such that one of the 3 batches tested did not fulfill the compendial requirement of more than $75 \%$ (the release was only $55.11 \%$ ). High variability in ASA release between batches was also found with Farmasal ${ }^{\mathbb{R}}$ at 10,20, and 30 minutes in buffer medium. The lowest effective dose of ASA as an antiplatelet drug for longterm use is $75 \mathrm{mg}$ of plain ASA, and this is equivalent to $100 \mathrm{mg}$ of enteric-coated ASA.

Conclusions All of the low-dose ASA preparations marketed in Indonesia are enteric-coated products, while Thrombo Aspilet $^{\mathbb{B}}$ is not only an enteric-coated but also a sustained-release product. Cardio Aspirin ${ }^{\circledR}$, followed by Aptor ${ }^{\mathbb{B}}$, has the right dose for low-dose enteric-coated preparation $(100 \mathrm{mg})$, produces consistent ASA release between batches, and the most stable towards deacetylation (antiplatelet inactivation). (Med J Indones 2009; 18: 161-6)
\end{abstract}

Key words: Dissolution profile, enteric coated, deacetylation 
Low-dose acetylsalicylic acid (ASA) has been used worldwide as an antiplatelet agent for prevention of cardiovascular death, myocardial infraction, and stroke in patients at high risk of occlusive vascular events. ${ }^{1}$ Among various antiplatelet agents, ASA is the oldest, the cheapest, and the most established, and therefore it becomes the standard drug to which other antiplatelets are compared. ${ }^{1}$

Among the above-mentioned high risk patients, antiplatelet therapy, especially acetylsalicylic acid (ASA), has been found to reduce the combined outcome of any serious vascular event by about one quarter, nonfatal myocardial infarction by one third, nonfatal stroke by one quarter, and vascular mortality by one sixth in a meta-analysis of $>100$ randomized trials. ${ }^{1}$ For this purpose, ASA has been used as life-long secondary and primary prevention medication; the most effective dose according to the meta-analysis is 75$150 \mathrm{mg}$ daily. The higher doses are less effective because higher doses also block the synthesis of prostacyclin which has platelet antiaggregation and vasodilator effects, while the lower doses are reported to "spare" prostacyclin. Higher doses also produce more gastrointestinal side effects and have higher risks of major bleeding. ${ }^{2}$ To reduce the gastrointestinal side effects, ASA is formulated as entericcoated tablets, ${ }^{3-5}$ which prevent the release of ASA in the stomach, and thereby preventing its perfusion into gastric mucosal cells which causes gastric injury.

The present study was conducted to compare the dissolution profiles of various enteric-coated low-dose ASA tablets marketed in Indonesia.

\section{METHODS}

\section{Products tested}

The products tested ( 3 batches for each product) were: Cardio Aspirin ${ }^{\circledR} 100 \mathrm{mg}$ tablet (Batch number/BN: BXC7A91, BXBVUP2, BXC8EZ1), Aptor ${ }^{\circledR} 100 \mathrm{mg}$ tablet (BN: 2D1137B, 7B1030A, 611584), Ascardia $^{\circledR} 80 \mathrm{mg}$ tablet (BN: B7G676G, B7C973F, B7G674G), Astika ${ }^{\circledR} 100$ mg tablet (BN: 760306, 761203, 761216), Farmasal ${ }^{\circledR} 100$ mg tablet (BN: TH 0921, PJ 0701, TC 0021), and Thrombo Aspilets $^{\circledR} 80$ mg tablet (BN: 7032501, 6063102, 7032401). All of the products were low-dose ASA that were produced in Indonesia. These products were supplied by PT Bayer Indonesia.

\section{Instruments}

The main instruments used were dissolution tester (United States Pharmacopoeia/USP type $)^{6}$ Erweka DT6, high performance liquid chromatograph (HPLC) with variable UV-Vis detector (HP 1100 series), spectrophotometer Beckman DU 7500i, and pH-meter Beckman ${ }^{\mathrm{TM}} 50$.

\section{Dissolution study}

This study was conducted at School of Pharmacy, Bandung Institute of Technology, Bandung, in the first quarter of 2008. There are two dissolution methods for ASA that are used and accepted in Indonesia; one of these methods is the method of USP/European Pharmacopoeia.

The apparatus used was USP apparatus 1 (basket) ${ }^{6}$ $100 \mathrm{rpm}$. The method was according to USP/European Pharmacopoeia, method $\mathrm{A},{ }^{6,7}$ using 2 media: medium 1 was $0.1 \mathrm{~N} \mathrm{HCl}(\mathrm{pH}=1)$, for acid stage, and medium 2 was phosphate buffer $\mathrm{pH} 6.8$, for buffer stage. The sampling time for acid stage was 120 minutes, while for buffer stage were every 10 minutes until 90 minutes. Spectrophotometry was used for the assay of ASA, at $280 \mathrm{~nm}$ for acid stage, and at $265 \mathrm{~nm}$ for buffer stage. The free salicylic acid was determined only at the end of buffer stage with HPLC method. There were 3 batches for each product tested, and 6 units for each batch. These batches and units were randomly taken from the market (a pharmacy in Jakarta) by PT Bayer Indonesia.

\section{Procedure $^{6,7}$}

Seven hundred fifty $\mathrm{mL}$ of medium $1(0.1 \mathrm{~N} \mathrm{HCl})$ was transferred to the dissolution vessel and warmed to $37^{\circ} \mathrm{C}\left( \pm 0.5^{\circ} \mathrm{C}\right)$. One tablet was placed in the basket, and the basket was put in the dissolution vessel, the stirrer was switched to $100 \mathrm{rpm}$ and run for 120 minutes. Five $\mathrm{mL}$ of the dissolution medium was taken as the first sample and the withdrawn dissolution medium was replaced with the same quantity of medium 1 . The aspirin concentration in the sample was determined spectrophotometrically at $280 \mathrm{~nm}$.

Immediately after sampling and medium replacement at the end of acid stage, $250 \mathrm{~mL}$ of medium $2(0.20 \mathrm{M}$ tribasic sodium phosphate, previously heated to $37^{\circ} \mathrm{C}$ ) was added. The $\mathrm{pH}$ was checked and was adjusted if necessary to $6.8 \pm 0.05$ with $2 \mathrm{~N} \mathrm{HCl}$ or $2 \mathrm{~N} \mathrm{NaOH}$. Five $\mathrm{mL}$ of the dissolution medium was withdrawn regularly every 10 minutes until 90 minutes. Each time of sampling, withdrawn medium was replaced with the same quantity of the same medium. The ASA concentrations in the samples were determined spectrophotometrically at $265 \mathrm{~nm}$ (at which the absorption is the same for both ASA and salicylic acid). 
Free salicylic acid concentration was determined only at the end of buffer stage (90 minutes) with validated HPLC method (with this method, the concentrations of ASA and salicylic acid can be determined simultaneously). The HPLC condition was as follows: the column was SGE, Wakosil C-18, $250 \times 4.6 \mathrm{~mm}, 5 \mu \mathrm{m}$; the mobile phase was phosphate buffer-acetonitrile $(60: 40) \mathrm{pH} 2.5$, $1 \mathrm{~mL} /$ minute, with UV detector at $237 \mathrm{~nm}$.

\section{Estimation of drug dissolution rates}

Drug dissolution rate was estimated during the main dissolution phase (between $10 \%$ and $90 \%$ of drug release)

\section{Estimation of similarity factors}

Similarity factor (f2) was estimated using time points from 10 to 40 minutes. Those points were taken in accordance to the general guideline in calculating similarity factor (not more than one point that was greater than $85 \%$ ). The similarity factors would show the similarity or the difference between the dissolution profiles of the products tested.

\section{Analytical methods}

The analytical methods (spectrophotometric and HPLC methods) were verified for selectivity, linearity, and precision. The selectivities of both methods were tested for possible interference from dissolution medium, not from tablet excipients since the excipients of each tablet tested were not available

\section{RESULTS}

No interference was found from the dissolution medium. The standard curve of ASA concentration vs absorbance by spectrophotometric method in acid medium was linear with $\mathrm{R}^{2}=0.9995$, and that in buffer medium was also linear with $\mathrm{R}^{2}=1$. The standard curve of salicylic acid concentration vs peak area by HPLC method was linear with $\mathrm{R}^{2}=0.9996$, and that of ASA concentration was also linear with $\mathrm{R}^{2}=0.9999$. The precision of ASA assay by spectrophotometric method in acid medium was high (coefficient of variation $/ \mathrm{CV}=$ $0.70 \%$ and $1.25 \%$ for absorbance of $1 \mathrm{ppm}$ and $4 \mathrm{ppm}$, respectively); and that in buffer medium was also high $(\mathrm{CV}=1.09,2.37$, and $1.17 \%$ for absorbance of $0.5 \mathrm{ppm}$, $45 \mathrm{ppm}$, and $90 \mathrm{ppm}$, respectively). The precision of salicylic acid assay by HPLC method was also high $(\mathrm{CV}=5.58,3.54$, and $2.88 \%$ for peak area of $1 \mathrm{ppm}, 50$ ppm, and $150 \mathrm{ppm}$, respectively)

\section{Dissolution results}

The results of the dissolution study of all ASA products tested are presented in Table 1 and Figure 1.

Table 1. Amount ( in mg) of ASA dissolved from 6 products tested within 2 stages (mean + SD)

\begin{tabular}{|c|c|c|c|c|c|c|}
\hline \multirow{2}{*}{$\begin{array}{l}\text { Time } \\
\text { (minute) }\end{array}$} & \multicolumn{6}{|c|}{ Product tested } \\
\hline & $\begin{array}{l}\text { Cardio Aspirin }^{\circledR} \\
\quad(100 \mathrm{mg})\end{array}$ & $\begin{array}{l}\text { Aptor }^{\circledR} \\
(100 \mathrm{mg})\end{array}$ & $\begin{array}{c}\text { Ascardia }^{\circledR} \\
(80 \mathrm{mg})\end{array}$ & $\begin{array}{l}\text { Thro.Aspilet } \\
\quad(80 \mathrm{mg})\end{array}$ & $\begin{array}{l}\text { Astika }^{\circledR} \\
(100 \mathrm{mg})\end{array}$ & $\begin{array}{c}\text { Farmasal }^{\circledR} \\
(100 \mathrm{mg})\end{array}$ \\
\hline $\begin{array}{l}\text { Acid medium } \\
(0.1 \mathrm{~N} \mathrm{HCl}) 120\end{array}$ & $\begin{array}{l}1.79 \pm 1.47 \\
(1.79 \%)\end{array}$ & $\begin{array}{l}3.70 \pm 1.11 \\
(3.70 \%)\end{array}$ & $\begin{array}{l}2.61 \pm 1.41 \\
(3.26 \%)\end{array}$ & $\begin{array}{l}5.53 \pm 3.00 \\
(6.92 \%)\end{array}$ & $\begin{array}{l}2.74 \pm 0.80 \\
(2.74 \%)\end{array}$ & $\begin{array}{l}3.25 \pm 1.71 \\
(3.25 \%)\end{array}$ \\
\hline \multicolumn{7}{|l|}{$\begin{array}{l}\text { Buffer medium } \\
\quad(\mathrm{pH} 6.8)\end{array}$} \\
\hline 0 & $1.79 \pm 1.47$ & $3.70 \pm 1.11$ & $2.61 \pm 1.41$ & $5.53 \pm 3.00$ & $2.74 \pm 0.80$ & $3.25 \pm 1.71$ \\
\hline 10 & $1.53 \pm 0.61$ & $11.43 \pm 6.62$ & $48.38 \pm 13.57$ & $14.08 \pm 2.35$ & $12.13 \pm 2.90$ & $38.84 \pm 34.66$ \\
\hline 20 & $14.86 \pm 1.96$ & $83.22 \pm 3.14$ & $86.46 \pm 4.70$ & $22.29 \pm 6.09$ & $65.93 \pm 5.00$ & $75.52 \pm 37.60$ \\
\hline 30 & $54.44 \pm 8.89$ & $103.87 \pm 1.53$ & $92.62 \pm 1.31$ & $30.97 \pm 7.47$ & $93.87 \pm 0.34$ & $94.86 \pm 20.08$ \\
\hline 40 & $90.25 \pm 0.56$ & $107.88 \pm 1.95$ & $91.94 \pm 1.38$ & $38.15 \pm 9.30$ & $100.05 \pm 1.83$ & $100.56 \pm 13.14$ \\
\hline 50 & $101.22 \pm 3.60$ & $108.34 \pm 2.43$ & $90.87 \pm 0.58$ & $44.59 \pm 11.35$ & $100.24 \pm 2.46$ & $102.59 \pm 9.07$ \\
\hline 60 & $102.06 \pm 4.28$ & $107.78 \pm 2.22$ & $89.81 \pm 0.44$ & $49.99 \pm 13.26$ & $99.70 \pm 1.45$ & $103.07 \pm 8.51$ \\
\hline 70 & $102.15 \pm 5.37$ & $107.12 \pm 2.51$ & $89.08 \pm 0.50$ & $54.75 \pm 15.26$ & $99.64 \pm 1.73$ & $103.51 \pm 7.89$ \\
\hline 80 & $102.84 \pm 4.67$ & $106.95 \pm 2.34$ & $88.92 \pm 0.97$ & $59.27 \pm 16.31$ & $99.13 \pm 1.71$ & $103.35 \pm 7.93$ \\
\hline 90 & $\begin{array}{l}100.90 \pm 4.70 \\
(100.90 \%)\end{array}$ & $\begin{array}{l}105.26 \pm 2.60 \\
(105.26 \%)\end{array}$ & $\begin{array}{l}88.02 \pm 1.26 \\
(109.80 \%)\end{array}$ & $\begin{array}{l}62.76 \pm 17.54 \\
(78.46 \%)\end{array}$ & $\begin{array}{l}98.81 \pm 2.80 \\
(98.81 \%)\end{array}$ & $\begin{array}{l}102.99 \pm 7.52 \\
(102.99 \%)\end{array}$ \\
\hline
\end{tabular}




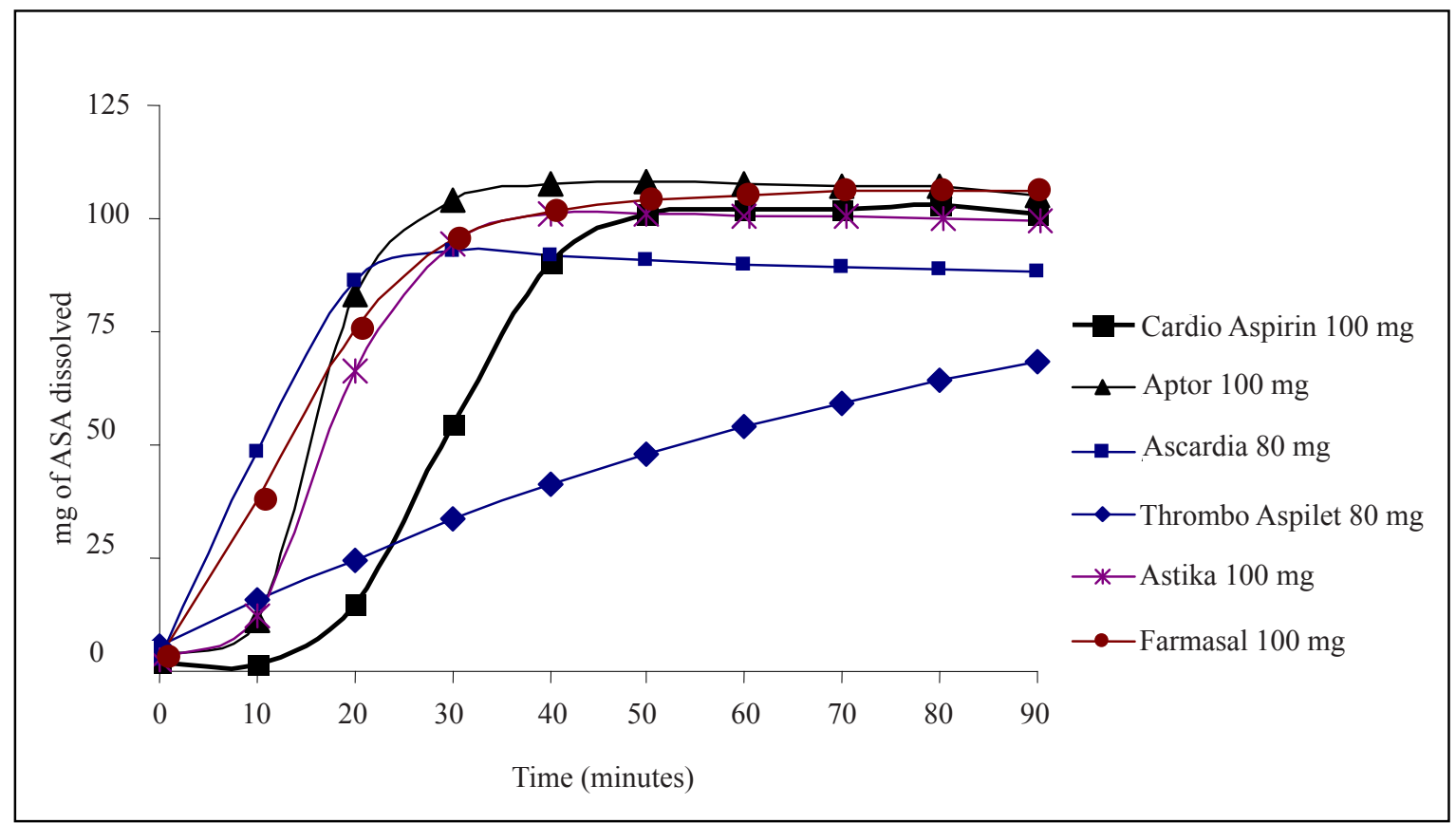

Figure 1. Dissolution profiles of ASA from different ASA products tested in buffer medium ( $p H$ 6.8)

\section{Acid resistance}

According to the compendial requirement, less than $10 \%$ of ASA should be released from enteric-coated formulations after 120 minutes in acid medium.

The amount of ASA release from each ASA product that was tested at the end of acid stage (120 minutes) can be seen in Table 1, and these were less than $10 \%$ of the stated potencies. Therefore, all of the tested drugs conformed to the compendial requirement for entericcoated product. Cardio Aspirin ${ }^{\circledR}$ tablet released the smallest amount of ASA during the acid stage, less than $2 \%$ of ASA $(1.79 \%)$ were released after 120 minutes of dissolution in acid medium. Meanwhile, the other drug products released more ASA which varied from 2.74\% to $6.92 \%$, but the differences were not significant.

\section{Dissolution profiles in buffer stage}

The results showed that the 6 ASA products had different drug release profiles. In buffer medium, ASA was released immediately from Ascardia ${ }^{\circledR}$ and Farmasal ${ }^{\circledR}$ tablets, but there was a lag time of about 10 minutes for Aptor ${ }^{\circledR}$ and Astika ${ }^{\circledR}$ tablets, and a longer lag time of about 20 minutes for Cardio Aspirin ${ }^{\circledR}$ tablet, which then fastly released ASA after 20 minutes of dissolution (see Figure 1).

A very different release profile was observed for Thrombo Aspilet ${ }^{\mathbb{B}}$ tablet, which showed sustained or slow release properties (see Figure 1).

Table 2. Amount (in \%) of ASA released at 90 minutes in buffer stage

\begin{tabular}{lcccccc}
\hline \multirow{3}{*}{ Batch } & \multicolumn{9}{c}{ Tested product } \\
\cline { 2 - 7 } & $\begin{array}{c}\text { Cardio Aspirin } \\
(100 \mathrm{mg})\end{array}$ & $\begin{array}{c}\text { Aptor } \\
(100 \mathrm{mg})\end{array}$ & $\begin{array}{c}\text { Ascardia } \\
(100 \mathrm{mg})\end{array}$ & $\begin{array}{c}\text { Th.Aspilet }^{\circ} \\
(100 \mathrm{mg})\end{array}$ & $\begin{array}{c}\text { Astika }^{\circ} \\
(100 \mathrm{mg})\end{array}$ & $\begin{array}{c}\text { Farmasal }^{\circ} \\
(100 \mathrm{mg})\end{array}$ \\
\hline 1 & 105.95 & 106.92 & 108.88 & 98.62 & 100.32 & 106.20 \\
2 & 96.67 & 106.61 & 111.82 & 55.11 & 100.53 & 108.38 \\
3 & 100.09 & 102.27 & 108.69 & 81.63 & 95.57 & 94.41 \\
\hline Mean & 100.90 & 105.26 & 109.80 & 78.46 & 98.81 & 102.99 \\
\hline
\end{tabular}


All of the products tested released more than $75 \%$ of ASA in 90 minutes of dissolution (compendial requirement), except for one of the 3 batches of Thrombo Aspilet ${ }^{\mathbb{B}}$ which showed less than $75 \%$ of drug released in 90 minutes (see Table 2).

\section{Free salicylic acid}

At the end of dissolution test (90 minutes of ASA in buffer phase), the amount of salicylic acid release from
ASA was measured. Deacetylation of ASA to salicylic acid causes ASA to lose its activity to acetylate COX-1 enzyme and to produce persistent antiplatelet effect.

The results of salicylic acid assay at the end of dissolution test are presented in Table 3. The amount of salicylic acid found during the dissolution test was smallest with Cardio Aspirin ${ }^{\circledR}$ tablet, followed by Aptor ${ }^{\circledR}$ tablet, ${\text { Farmasal },{ }^{\circledR} \text { Ascardia }}^{\circledR}$, Astika ${ }^{\circledR}$ and Thrombo Aspilet ${ }^{\circledR}$.

Table 3. The amount of salicylic acid (in \%*) observed at the end of the dissolution test

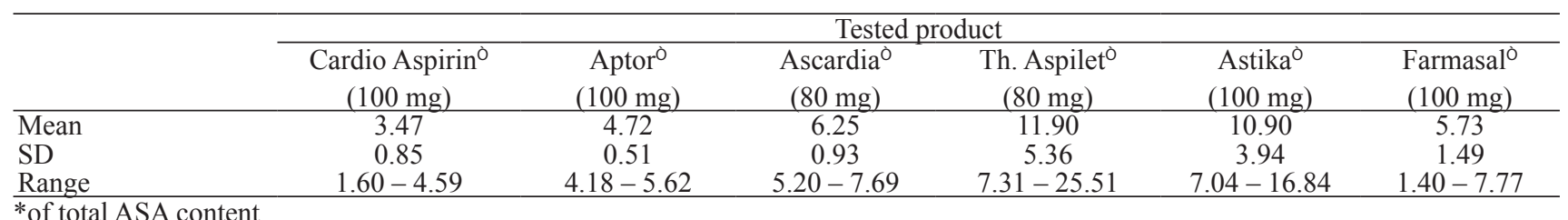

\section{DISCUSSION}

All the investigated low-dose ASA products in this study were enteric-coated formulations, and all of the products conformed to the compendial requirement of releasing ASA less than $10 \%$ after 120 minutes in acid medium. Cardio Aspirin ${ }^{\circledR}$ tablet released the lowest amount of ASA (less than 2\%), which suggested that it was the most acid resistant compared to the other products (see Table 1), but the differences were not significant.

As enteric-coated products, the ASA should be released in buffer medium, and the compendial requirement requires that more than $75 \%$ of ASA should be released in 90 minutes. Again, our data showed that all of the products fulfilled this requirement, except Thrombo Aspilet $^{\circledR}$, as one of the 3 tested batches released ASA only $55 \%$ at the end of the dissolution test (see Table 2).

Enteric-coated low-dose ASA has been shown to have less antiplatelet activity compared to equivalent doses of plain ASA. ${ }^{8}$ Lower bioavailability of these preparations and poor absorption from the higher $\mathrm{pH}$ environment of the small intestine may result in inadequate platelet inhibition. Enteric-coated ASA preparations release ASA into the upper small intestine, which has a near neutral $\mathrm{pH}$, causing ASA to become unstable and some are deacetylated to salicylic acid. Deacetylation of ASA to salicylic acid causes ASA to lose its activity to acetylate serine 529 at Cox-1 enzyme, which produces irreversible inhibition of the enzyme in platelet, and thereby causes persistent antiplatelet effect. Therefore, deacetylation causes inactivation of ASA in producing persistent antiplatelet effect
Enteric-coated preparations may also differ in their rate of dissolution at the intestinal $\mathrm{pH}(\mathrm{pH}=6)$. Furthermore, enteric-coated $75 \mathrm{mg}$ ASA preparation was estimated to deliver a dose equivalent to $50 \mathrm{mg}$ plain ASA. ${ }^{8}$ This may be true for enteric-coated $80 \mathrm{mg}$ ASA preparations as was shown in the present study for Ascardia $^{\circledR}$ and Thrombo Aspilet ${ }^{\circledR}$. To ensure adequate inhibition of thromboxane production, plain $75 \mathrm{mg}$ ASA or an equivalent dose of enteric-coated ASA (estimated to be around $100 \mathrm{mg}$ ) should be used. ${ }^{8}$ The most effective dose of ASA as an antiplatelet drug for long-term use is 75 to $150 \mathrm{mg} .{ }^{1}$ Since the side effects of ASA is dose-dependent, ${ }^{2}$ then $75 \mathrm{mg}$ of plain ASA would be the right choice, and this is equivalent to $100 \mathrm{mg}$ of entericcoated ASA. ${ }^{8}$

Farmasal ${ }^{\circledR}$ is an enteric-coated $100 \mathrm{mg}$ ASA preparation, but it had a very high variability in ASA release between batches, especially at 10,20, and 30 minutes in buffer medium (the standard deviations were more than 20\%) (see Table 1), which might indicate inconsistency in the manufacturing process.

Cardio Aspirin $^{\circledR}$, Aptor $^{\circledR}$, and Astika ${ }^{\circledR}$ are 100 mg enteric-coated tablets, and have shown low variabilities of ASA release between batches (Table 1). Aptor ${ }^{\mathbb{B}}$ and Astika $^{\circledR}$ had a lag time of about 10 minutes, while Cardio Aspirin ${ }^{\circledR}$ had a lag time of about 20 minutes, before ASA was fastly released afterwards. These facts indicated that the tablets of Aptor $^{\circledR}$ and Astika ${ }^{\circledR}$ required 10 minutes, while Cardio Aspirin ${ }^{\circledR}$ tablet required 20 minutes to dissolve at the near neutral $\mathrm{pH}$ of the small intestine. However, Astika ${ }^{\circledR}$ showed a high variability in producing salicylic acid compared to Aptor ${ }^{\circledR}$ and Cardio 
Aspirin $^{\circledR}$ at the end of buffer stage (see Table 3), which indicated that it was more unstable in intestinal $\mathrm{pH}$ compared to Aptor $^{\mathbb{B}}$ and Cardio Aspirin ${ }^{\mathbb{B}}$. Therefore, among these 3 enteric-coated tablets that contain $100 \mathrm{mg}$ ASA, Cardio Aspirin ${ }^{\circledR}$ and Aptor ${ }^{\circledR}$ were the most stable towards deacetylation, and produced the lowest amount of salicylic acid at the end of buffer stage (90 minutes), as shown in Table 3.

Our data also showed that Thrombo Aspilet ${ }^{\mathbb{R}}$ had both enteric-coated and sustained-release properties. This sustainedrelease ASA preparation produced more salicylic acid (see Table 3), may be because it released ASA steadily but in small amounts, and therefore more prone to deacetylation. This instability towards deacetylation was shown in the high variability in producing salicylic acid at the end of the dissolution test, as shown in Table 3. As already mentioned, Thrombo Aspilet ${ }^{\mathbb{B}}$ also showed a high variability between batches in ASA release at 90 minutes in buffer stage (see Table 2). These results were in accordance with the study of Dooley et al, ${ }^{9}$ which showed that the slow-release $75 \mathrm{mg}$ ASA was worse in terms of variation in platelet aggregation and serum $\mathrm{TXB}_{2}$ levels in healthy volunteers. Consequently, sustained-release critically low doses of ASA may result in subtherapeutic effects. ${ }^{9}$

Enteric-coated ASA may cause rectal bleeding, ulceration of ascending colon, collageneous colitis, and diverticular bleeding from a duration of use ranging from 18 days to 15 years. ${ }^{10}$ However, enteric-coated ASA 100 mg/day caused significantly less gastroduodenal damage than the same dose of plain ASA. ${ }^{4}$ This is due to enteric-coated ASA that released ASA mainly in the intestine, therefore decreased ulcerogenicity in the upper gastroduodenum and shifted the site of damage to the more distal intestine. ${ }^{10}$ Moreover, the sustained-release preparations, due to the sustained release of the drug and its longer presence within the intestinal tract, induced more local damage in the distal intestinal wall in addition to the systemic intestinal effect. ${ }^{10-12}$ This fact was due to a significant increase in the permeability of the lower intestine produced by the sustained-release formulations, but not of the gastroduodenum, while the immediate-release products significantly increased the permeability at the gastroduodenal level. ${ }^{11,12}$ Nevertheless, the gastrointestinal blood loss with entericcoated ASA was less compared to that with plain ASA, but more compared with control, ${ }^{13}$ which implies that the gastric contribution to gastrointestinal ASA induced blood loss may be more important than the contribution of the small intestine. ${ }^{13}$ This reduced GI blood loss with entericcoated ASA was accompanied by decreased gastroduodenal mucosal damage compared with plain ASA, as measured endoscopically and symptomatically. ${ }^{14}$

In short, sustained-release low-dose ASA showed high variability in ASA release between batches and in pro- ducing salicylic acid (deacetylation) at the end of the dissolution test, and therefore may be less effective in inhibiting platelet aggregation. It may also cause more local damage in the distal intestine.

In conclusion, all of the investigated low-dose ASA products in this study are enteric-coated formulations and are marketed in Indonesia. Thrombo Aspilet ${ }^{\circledR}$ besides an enteric-coated is also a sustained-release product. Cardio Aspirin $^{\circledR}$, followed by Aptor ${ }^{\circledR}$, has the right dose for lowdose enteric-coated preparation $(100 \mathrm{mg})$, produces consistent ASA release between batches, and the most stable towards deacetylation (antiplatelet inactivation).

\section{Acknowledgment}

We thank PT Bayer Indonesia for funding the study.

\section{REFERENCES}

1. Antithrombolic Trialists' Collaboration. Collaborative meta-analysis of randomized trials of antiplatelet therapy for prevention of death, myocardial infarction, and stroke in high patients. BMJ. 2002; 324: 71-86.

2. Patrono C, FitzGerald GA, Hirsh J, Roth G. Platelet-active drugs: the relationships among dose, effectiveness, and side effects. Chest. 2004; 126: 2345-645.

3. Dammann HG. Gastroduodenal tolerability profile of low-dose enteric-coated ASA. Gastroenterology Intl. 1998; 11(4): 205-16.

4. Dammann HG, Burkhardt F, Wolf N. Enteric coating of ASA significantly decreases gastroduodenal mucosal lesions. Aliment Pharmacol Ther. 1999; 13;1109-14.

5. Darius H. Acetylsalicylic acid (ASA) ${ }^{\circledR}$ protect: observational study documents good tolerability. Pharm Ztg. 2006;151: 26-34.

6. United States Pharmacopoeia. 31st ed. Rockville: US Pharmacopoeial Convention; 2008.

7. European Pharmacopoeia. 6th ed, vol 1. Strassburg: European Directorate for the Quality of Medicines \& Health Care (EDQM); 2008.

8. Cox D, Maree AO, Dooley M, Conroy R, Byrne MF, Fitzgerald DJ. Effect of enteric coating on antipletelet activity of lowdose ASA in healthy volunteers. Stroke. 2006; 37: 2153-8.

9. Dooley M, Byrne M, Fitzgerald D, Cox D. Variation in the response to low-dose ASA preparations designed to inhibit platelets. Proceedings of the 43rd Annual Meeting of Am Soc Hematol (ASH); 2001 May 15-19; Orlando, USA, Poster No. 221.

10. Davis NM. Sustained release and enteric coated NSAIDs: are they really G1 safe. J Pharm Pharmaceut Sci. 1999; 2(1): 5-14.

11. Vakily M, Khorasheh F, Jamali F. Dependency of gastrointestinal toxicity on release rate of Tiaprofenic acid: a novel pharmacokinetic-pharmacodynamic model. Pharmaceut Res. 1999; 16 (1): 123-9.

12. Davis NM, Jamali F. Influence of dosage form on the gastroenteropathy of flurbiprofen in the rat: evidence of shift in the toxicity site. Pharmaceut Res. 1997; 14 (11): 1597-600.

13. Savon JJ, Allen ML, DiMarino AJ, Hermann GA, Krum RP. Gastrointestinal blood loss with low dose $(325 \mathrm{mg})$ plain and enteric-coated ASA administration. Am J Gastroenterol. 1995; 90 (4): 581-5.

14. Hoftiezer JW, Silvoso GR, Burks M, Ivey KI. Comparison of the effects of regular and enteric-coated ASA on gastroduodenal mucosa of man. Lancet. 1980; 2 : 609-12. 